2008-10-10

\title{
Helicobacter pylori-induced inhibition of vascular endothelial cell functions: a role for VacA-dependent nitric oxide reduction
}

Nicholas P. Toblin

Dublin City University

Gary Henehan

Technological University Dublin, gary.henehan@tudublin.ie

Ronan P. Murphy

Dublin City University

See next page for additional authors

Follow this and additional works at: https://arrow.tudublin.ie/ehsiart

Part of the Medicine and Health Sciences Commons

\section{Recommended Citation}

Tobin NP, Henehan GT, Murphy RP, Atherton JC, Guinan AF, Kerrigan SW, Cox D, Cahill PA, Cummins PM. Helicobacter pylori-induced inhibition of vascular endothelial cell functions: a role for VacA-dependent nitric oxide reduction. Am J Physiol Heart Circ Physiol. 2008 Oct;295(4):H1403-13. doi: 10.1152/ ajpheart.00240.2008. Epub 2008 Jul 25. PMID: 18660451.

This Article is brought to you for free and open access by the ESHI Publications at ARROW@TU Dublin. It has been accepted for inclusion in Articles by an authorized administrator of ARROW@TU Dublin. For more information, please contact arrow.admin@tudublin.ie, aisling.coyne@tudublin.ie,gerard.connolly@tudublin.ie.

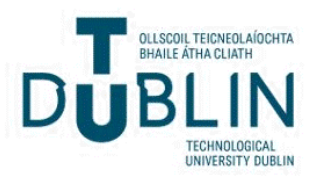


Authors

Nicholas P. Toblin, Gary Henehan, Ronan P. Murphy, John P. Atherton, Anthony F. Guinan, Steven W. Kerrigan, Dermot Cox, Paul A. Cahill, and Philip M. Cummins 


\title{
Helicobacter pylori-induced inhibition of vascular endothelial cell functions:
} a role for VacA-dependent nitric oxide reduction

\author{
Nicholas P. Tobin, ${ }^{1}$ Gary T. Henehan, ${ }^{2}$ Ronan P. Murphy, ${ }^{1}$ John C. Atherton, ${ }^{3}$ Anthony F. Guinan, ${ }^{1}$ \\ Steven W. Kerrigan, ${ }^{4}$ Dermot Cox ${ }^{4}$ Paul A. Cahill, ${ }^{1}$ and Philip M. Cummins ${ }^{1}$ \\ ${ }^{1}$ School of Biotechnology, Dublin City University; ${ }^{2}$ School of Food Science and Environmental Health, Dublin Institute \\ of Technology; ${ }^{3}$ Wolfson Digestive Diseases Centre, University Hospital Nottingham; and ${ }^{4}$ Molecular and Cellular \\ Therapeutics, Royal College of Surgeons of Ireland, Dublin, Ireland
}

Submitted 7 March 2008; accepted in final form 23 July 2008

\begin{abstract}
Tobin NP, Henehan GT, Murphy RP, Atherton JC, Guinan AF, Kerrigan SW, Cox D, Cahill PA, Cummins PM. Helicobacter pylori-induced inhibition of vascular endothelial cell functions: a role for VacA-dependent nitric oxide reduction. Am J Physiol Heart Circ Physiol 295: H1403-H1413, 2008. First published July 25, 2008; doi:10.1152/ajpheart.00240.2008.Epidemiological and clinical studies provide compelling support for a causal relationship between Helicobacter pylori infection and endothelial dysfunction, leading to vascular diseases. However, clear biochemical evidence for this association is limited. In the present study, we have conducted a comprehensive investigation of endothelial injury in bovine aortic endothelial cells (BAECs) induced by $H$. pylori-conditioned medium (HPCM) prepared from H. pylori 60190 [vacuolating cytotoxin $\mathrm{A}\left(\mathrm{Vac}^{+}\right)$]. BAECs were treated with either unconditioned media, HPCM $(0-25 \% \mathrm{vol} / \mathrm{vol})$, or Escherichia coliconditioned media for $24 \mathrm{~h}$, and cell functions were monitored. $\mathrm{Vac}^{+}$ HPCM significantly decreased BAEC proliferation, tube formation, and migration (by up to $44 \%, 65 \%$, and $28 \%$, respectively). Posttreatment, we also observed sporadic zonnula occludens- 1 immunolocalization along the cell-cell border, and increased BAEC permeability to FD40 Dextran, indicating barrier reduction. These effects were blocked by 5-nitro-2-(3-phenylpropylamino)benzoic acid (VacA inhibitor) and were not observed with conditioned media prepared from either VacA-deleted H. pylori or E. coli. The cellular mechanism mediating these events was also considered. $\mathrm{Vac}^{+}$HPCM (but not $\mathrm{Vac}^{-}$) reduced nitric oxide (NO) by $>50 \%$, whereas $S$-nitroso- $N$ acetylpenicillamine, an NO donor, recovered all $\mathrm{Vac}^{+} \mathrm{HPCM}-$ dependent effects on cell functions. We further demonstrated that laminar shear stress, an endothelial NO synthase/NO stimulus in vivo, could also recover the $\mathrm{Vac}^{+}$HPCM-induced decreases in BAEC functions. This study shows, for the first time, a significant proatherogenic effect of $H$. pylori-secreted factors on a range of vascular endothelial dysfunction markers. Specifically, the VacA-dependent reduction in endothelial NO is indicated in these events. The atheroprotective impact of laminar shear stress in this context is also evident.
\end{abstract}

vacuolating cytotoxin $\mathrm{A}$; shear stress

HELICOBACTER PYLORI is a gram-negative, spiral-shaped bacterium that colonizes the human gastric epithelium and is the causative agent in chronic gastritis, peptic ulceration, and gastric carcinoma (33). In recent years, evidence that chronic $H$. pylori infection plays a role in the extra-gastric initiation and progression of vascular diseases has been mounting (14, $16,20,35)$. Seroepidemiological and eradication studies have demonstrated a causal relationship between $H$. pylori infection and atherosclerosis $(3,16,31)$. Elevated levels of homocys-

Address for reprint requests and other correspondence: P. M. Cummins, School of Biotechnology, Dublin City Univ., Dublin, Ireland (e-mail: phil. cummins@dcu.ie). teine (9), asymmetric dimethylarginine (ADMA) (45), and serum lipids $(25,39)$, all independent risk factors for vascular disease, have also been associated with $H$. pylori infection.

Various mechanisms have been proposed to account for the contribution of $H$. pylori to vascular diseases. Molecular mimicry, oxidative modifications, bacterium-platelet interactions, and even direct plaque modification, leading to endothelial dysfunction or inflammation, have been proposed $(12,26$, 43). With respect to plaque modification, perhaps the most persuasive single piece of evidence supporting this role was the identification of $H$. pylori DNA in atherosclerotic plaques. This finding was key in pointing to the direct involvement of the bacterium in this specific pathology $(1,2,17,36)$.

Endothelial dysfunction provides a crucial link by which $H$. pylori, and indeed other pathogens, may contribute to atherogenesis $(55,60)$. In this regard, a number of in vitro studies have previously reported $H$. pylori-dependent endothelial injury by way of reduced angiogenesis $(28,29)$, reduced proliferation $(29,37,52)$, and elevated apoptosis (37). H. pylori-dependent elevations in neutrophil recruitment and transendothelial migration have also been reported $(5,15)$. Although this evidence points to a role for $H$. pylori in endothelial dysfunction in vivo, certain key issues remain unresolved. Many of these studies are limited to only one aspect of endothelial dysfunction and frequently lack substantial mechanistic elaboration with respect to the induction of cellular injury. Moreover, most studies were carried out using whole cell aqueous extracts of $H$. pylori (which may include unforeseen target protein modifications resulting from extract preparation) and have not directly examined the specific contribution of secreted virulence factors (using bacterially conditioned media, for example). The demonstrated translocation of the bacterium and its biochemical components from the gastric mucosa into the systemic circulation $(21,47,54)$ is in agreement with the endothelium exposure to $H$. pylori-secreted virulence factors. Thus, at atherosclerotic plaque sites, these factors may reach sufficiently high levels within the vessel wall microenvironment (relative to the systemic circulation) to influence endothelial dysfunction and lesion development.

A model incorporating $H$. pylori in atherosclerosis must demonstrate clear biochemical mechanisms whereby the bacterium can cause vascular endothelial dysfunction. In the present study, we have conducted a comprehensive investigation of endothelial injury in bovine aortic endothelial cells

\footnotetext{
The costs of publication of this article were defrayed in part by the payment of page charges. The article must therefore be hereby marked "advertisement" in accordance with 18 U.S.C. Section 1734 solely to indicate this fact.
} 
(BAECs) in response to treatment with H. pylori-conditioned medium (HPCM). Our findings show significant effects on endothelial proliferation, tube formation, migration, and barrier properties. Moreover, we show for the first time that multiple aspects of $H$. pylori-induced endothelial dysfunction can be attributed to vacuolating cytotoxin A (VacA), a H. pylorisecreted virulence factor that elicits its effects by modulating plasma and mitochondrial membrane ion permeability (63) as well as altering intracellular vesicular trafficking leading to vacuole formation (57). Finally, the VacA-dependent reduction in endothelial nitric oxide (NO) is indicated in our model, as is the atheroprotective influence of laminar shear stress.

\section{MATERIALS AND METHODS}

All reagents used in this study were of the highest purity and, unless otherwise stated, were obtained from Sigma-Aldrich.

\section{Cell Culture}

BAECs were obtained from Coriell Cell Repositories (NJ-Cat No. AG08500). BAECs were routinely grown in RPMI-1640 media supplemented with $10 \%$ fetal calf serum and antibiotics $(50 \mathrm{U} / \mathrm{ml}$ penicillin and $50 \mu \mathrm{g} / \mathrm{ml}$ streptomycin), hereafter referred to as RPMI complete media. The cells were maintained in a humidified atmosphere of $5 \% \mathrm{CO}_{2}-95 \%$ air at $37^{\circ} \mathrm{C}$. For all experiments, cells between passages 7 and 14 were used.

\section{Bacterial Culture and Conditioned Media Preparation}

H. pylori $60190 \mathrm{Vac}^{+}$(ATCC No. 49503) and $\mathrm{Vac}^{-}$(VacA gene-deleted 60190; John Atherton, University Hospital Nottingham) strains were innoculated onto pylori agar plates (BioMérieux; Marcy $1^{\prime}$ Etoile) and incubated at $37^{\circ} \mathrm{C}$ under microaerobic conditions for 7 days. Bacterial colonies were scraped off and resuspended in $3 \mathrm{ml}$ phosphate-buffered saline (PBS). The optical density of the suspension was determined at $600 \mathrm{~nm}$ and adjusted by dilution in PBS to a final absorbance of 1.0 (corresponding to $5 \times 10^{9} \mathrm{bacteria} / \mathrm{ml}$ ) (26). Exactly $2.5 \mathrm{ml}$ of bacterial suspension were added to a T25 tissue culture flask containing $40 \mathrm{ml}$ of RPMI complete media and incubated at $37^{\circ} \mathrm{C}$ under microaerobic conditions for $24 \mathrm{~h}$. The conditioned media was then sterile filtered using a $0.2 \mu \mathrm{m}$ filter to yield HPCM. Dilutions of HPCM in RPMI complete media were routinely prepared for individual experiments (i.e., undiluted $\mathrm{HPCM}=$ $100 \% \mathrm{vol} / \mathrm{vol} ; 1: 2$ dilution $=50 \% \mathrm{vol} / \mathrm{vol}$; control $=0 \% \mathrm{vol} / \mathrm{vol}$, etc.). Conditioned media using Escherichia coli (strain BL21) was also prepared, sterile filtered, and diluted in RPMI complete media in a similar manner to HPCM for inclusion as a gram-negative bacterial control in specific experiments $(0.01-0.1 \% \mathrm{vol} / \mathrm{vol})$. Most experiments involved the treatment of static (unsheared) BAECs with either RPMI or bacterium-conditioned media, after which changes in cell proliferation, migration, tube formation, and barrier function were monitored. For inhibition studies, $10 \mu \mathrm{g} / \mathrm{ml}$ jack bean urease (15), $100 \mu \mathrm{M}$ 5-nitro-2-(3-phenylpropylamino)benzoic acid (NPPB; a VacA inhibitor) (63), and $1 \mathrm{mM} N^{\omega}$-nitro-L-arginine methyl ester [L-NAME; an endothelial NO synthase (eNOS) inhibitor] were included in media when required. The NO donor $S$-nitroso- $N$ acetyl-penicillamine (SNAP) was also employed for specific studies (proliferation, $0.25 \mu \mathrm{M}$; tube formation, $5 \mu \mathrm{M}$; migration, $1 \mu \mathrm{M}$; and permeability/immunocytochemistry, $1 \mu \mathrm{M}$ ). Bradford assay was used for protein measurement with BSA as standard (4).

\section{BAEC Proliferation}

Flow cytometry (Becton Dickinson FACSCaliber) was routinely used to monitor BAEC proliferation (and apoptosis). Cells were seeded into six-well plates $\left(2 \times 10^{4}\right.$ cells/well $)$ and allowed to grow for $24 \mathrm{~h}$. The cells were then washed once with Hanks' balanced salt solution before $1 \mathrm{ml}$ of $5 \mu \mathrm{M}$ carboxy-fluorescein diacetate succinimidyl ester (CFDA; prepared in Hanks') was added to each well for $15 \mathrm{~min}$ at $37^{\circ} \mathrm{C}$. Following incubation, CFDA was replaced with fresh media and cells were allowed to recover for $12 \mathrm{~h}$ before overnight quiescence. The cells were then treated with HPCM $(0-25 \% ; 2$ $\mathrm{ml} / \mathrm{well}$ ), harvested every $24 \mathrm{~h}$ for up to 5 days by trypsinization/ centrifugation, and washed twice with $1 \mathrm{ml}$ ice-cold PBS (containing $0.1 \%$ BSA) before fluorescence-activated cell sorting (FACS) analysis. Proliferation was also routinely monitored by cell counting using a bright line hemocytometer. For cell counting studies, proliferation was typically reported for day 4. For NPPB studies, proliferation was monitored over a 2-day period.

\section{BAEC Migration}

Wound heal assay was routinely used to monitor BAEC migration, as previously described (13). BAECs were seeded into 24-well plates $\left(5 \times 10^{4}\right.$ cells/well $)$ and allowed to grow to confluency. The cells were then quiesced overnight and treated with HPCM $(0-25 \%+2.5$ $\mu \mathrm{g} / \mathrm{ml}$ mitomycin C; $1 \mathrm{ml} / \mathrm{well}$ ) for $24 \mathrm{~h}$. Following treatment, a wound or scratch was created in each well by scraping cells with a pipette tip. Cells were then washed, and HPCM was replaced. To monitor wound closure, the wound was photographed at two predefined positions every $2 \mathrm{~h}$ and the distance between the two wound edges was digitally measured using Macintosh Free Ruler v1.6. Migration was expressed in terms of the average decrease in wound width for the assay period.

\section{BAEC Tube Formation}

Collagen gel assay was routinely used to monitor BAEC tube formation, as previously described (66). BAECs were seeded into 24 -well plates $\left(5 \times 10^{4}\right.$ cells/well $)$ and allowed to grow to confluency. Cells were then quiesced overnight and treated with HPCM $(0-25 \%$; $1 \mathrm{ml} / \mathrm{well}$ ) for $24 \mathrm{~h}$. Following treatment, cells were trypsinized, resuspended in HPCM, and seeded into collagen gels (24-well format; $\left.1.5 \times 10^{4} \mathrm{cells} / \mathrm{well}\right)$. Tube formation proceeded overnight $(16-18 \mathrm{~h})$ and was monitored by standard light microscopy with digital photography (Olympus SP-350 camera). Four random fields were photographed from each well, and tube formation was quantified by measuring the average length of the network of connected cells using imaging software for life sciences and microscopy (Olympus cell^^ $\mathrm{F}$ Image and Analysis software).

\section{BAEC Barrier Property}

Transwell permeability assay. BAECs were seeded into six-well plates $\left(5 \times 10^{4}\right.$ cells/well $)$ and allowed to grow to confluency. Cells were then quiesced overnight and treated with HPCM (25\%) for $24 \mathrm{~h}$ under 10 dynes $/ \mathrm{cm}^{2}$ laminar shear (i.e., to induce barrier formation), as described in Shear Stress. Posttreatment, cells were trypsinized and replated $\left(2.5 \times 10^{5}\right.$ cells/well) into Millipore-Clear plates with polyester membrane inserts (6-well format; $0.4 \mu \mathrm{m}$ pore; $24 \mathrm{~mm}$ diameter; Millipore). At confluency, transendothelial permeability was monitored as previously described (7) using fluorescein isothiocyanatelabeled 40-kDa Dextran (FD40 Dextran). Results are given as percent transendothelial exchange of FD40 Dextran (taken as the total subluminal fluorescence at a given time expressed as percentage of total abluminal fluorescence at $\mathrm{t}=0$ ).

Zonnula occludens-1 immunocytochemistry. BAECs were seeded into six-well Bioflex plates $\left(5 \times 10^{4}\right.$ cells/well) (Dunn Labortechnik, Asbach, Germany) and allowed to grow to confluency. Cells were then quiesced overnight and treated with HPCM $(25 \%)$ for $24 \mathrm{~h}$ under $10 \%$ equibiaxial cyclic strain (i.e., to induce barrier formation), as previously described (8). Posttreatment, Bioflex wells were excised with a scalpel and prepared for immunocytochemistry, again as previously described (8). The primary antibody was $0.25 \mu \mathrm{g} / \mathrm{ml} \mathrm{rabbit}$ anti-zonnula occludens-1 (ZO-1) monoclonal IgG for $2 \mathrm{~h}$ (Zymed, San 
Francisco, CA). The secondary antibody was 1:400 Alexa 488conjugated goat anti-rabbit IgG for $1 \mathrm{~h}$ (Molecular Probes, Eugene, OR). Controls included the exclusion of primary antibody and 4,6diamidino-2-phenylindole (DAPI) nuclear staining $(500 \mathrm{ng} / \mathrm{ml}$; 3 min).

\section{Shear Stress}

With the use of an orbital rotator to apply physiological levels of laminar shear stress, as previously described (7), the impact of shear on HPCM-dependent changes in BAEC proliferation, tube formation, and migration was examined. BAECs were seeded into six-well plates $\left(5 \times 10^{4}\right.$ cells/well $)$ and allowed to grow to confluency. Cells were quiesced overnight and treated with HPCM (25\%; $4 \mathrm{ml} /$ well) for $24 \mathrm{~h}$ at either 0,1 , or $10 \mathrm{dynes} / \mathrm{cm}^{2}$ of shear. Postshear, BAECs were incorporated into proliferation, tube formation, and migration assays (as described in BAEC Proliferation, BAEC Migration, and BAEC Tube Formation).

\section{Nitrite Assay}

BAECs were seeded into six-well plates $\left(5 \times 10^{4}\right.$ cells/well $)$ and allowed to grow to confluency. Cells were quiesced overnight and treated with HPCM $(25 \% ; 2 \mathrm{ml} /$ well $)$ for $24 \mathrm{~h}$. Assay for nitrite in BAEC media following experimental treatments was performed by 2,4-diaminonapthalene assay, as previously described (6). NO levels were determined on a per well basis and were not normalized to cell number per well because all wells were initially seeded with an identical number of cells and no statistical difference in cells per well was observed between conditions following treatment, as determined by hemocytometer cell counting.

\section{Western Immunoblotting}

Following shearing experiments, BAECs were harvested and total lysate samples were resolved by $10 \%$ SDS-PAGE under reducing conditions according to the method of Laemmli (38). Gels were electroblotted onto nitrocellulose membranes using an ATTO semidry transfer system $(1 \mathrm{~h} ; 100 \mathrm{~V})$, and membranes were blocked for $2 \mathrm{~h}$ in Tris-buffered saline [10 $\mathrm{mM}$ Tris $(\mathrm{pH} 8.0)$ and $150 \mathrm{mM} \mathrm{NaCl}]$ containing $5 \% \mathrm{wt} / \mathrm{vol} \mathrm{BSA}$. The preparation of BAEC lysates, protein assay, and immunostaining for eNOS have all been described previously $(6,7)$.

\section{Statistical Analysis}

Results are expressed as means \pm SE. Experimental points were performed in triplicate with a minimum of three independent experiments $(n=3)$. Statistical comparisons between control and treatment groups were made by Student's unpaired $t$-test.
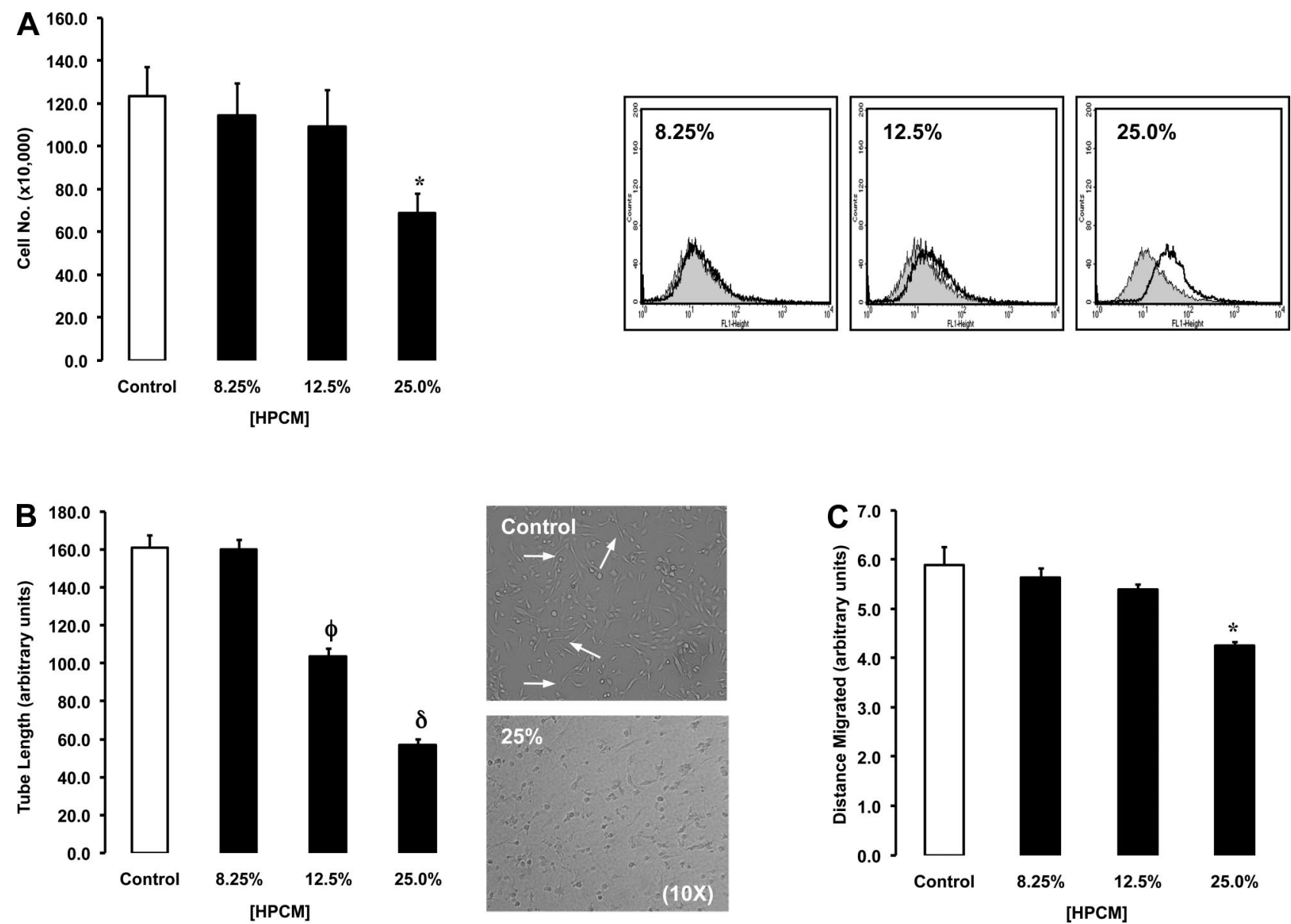

Fig. 1. Effect of Helicobacter pylori-conditioned medium (HPCM) on bovine aortic endothelial cell (BAEC) functions. BAECs were treated with vacuolating cytotoxin $\mathrm{A}(\mathrm{Vac})^{+} \mathrm{HPCM}(0-25 \%)$ and monitored for changes in proliferation (4 days), tube formation (24 h), and migration (24 h). Control is unconditioned RPMI-1640 complete media. HPCM treatment times are shown in parentheses. Histograms were averaged from 3 independent experiments \pm SE. $A$ : proliferation. $* P \leq 0.01$ vs. control. Fluorescence-activated cell sorting (FACS) analysis (right) shows untreated control cells (gray-shaded area) relative to HPCM-treated cells (unshaded area). $B$ : tube formation. $\phi P \leq 0.001 ; \delta P \leq 0.0001$ vs. control. Representative images (right) show reduction in endothelial sprouting (white arrows) following treatment. $C$ : migration. $* P \leq 0.01$ vs. control. 


\section{RESULTS}

\section{HPCM Decreases BAEC Functions: Proliferation, Tube Formation, and Migration}

The effect of HPCM $(0-25 \%)$ on BAEC proliferation, tube formation, and migration was examined. At 25\% HPCM, we observed a substantial decrease in proliferation, as determined by cell counts (Fig. 1A). This finding was also verified by FACS analysis (Fig. 1A). Significant decreases in both tube formation and migration were also noted at 25\% HPCM (Fig. $1, B$ and $C$ ).

The effect of NPPB (a VacA inhibitor) on the above changes was next examined. In the absence of NPPB, HPCM $(25 \%)$ reduced proliferation, tube formation, and migration, as described above (Fig. 2, $A-C$ ). These effects were completely prevented by NPPB. A baseline inhibitory effect of NPPB on proliferation and tube formation levels was also noted $(44,58)$.

\section{HPCM Decreases BAEC Barrier Properties}

The effect of HPCM on BAEC barrier properties was examined. Cells were treated with HPCM (25\%) in the absence and presence of NPPB and stained for ZO-1 immunoreactivity. Consistent with an intact endothelial barrier, ZO-1 exhibited continuous immunolocalization along the cell-cell border in untreated controls (Fig. 2Di). HPCM treatment led to ZO-1 localization becoming extremely jagged and sporadic along the cell-cell border (Fig. 2Diii), an effect that was prevented by NPPB (Fig. 2D, $i i$ and $i v$ ).

\section{HPCM-Induced Changes in BAEC Function are Mediated by $\operatorname{VacA}$}

The role of VacA in these events was examined. BAECs were separately treated with HPCM (25\%) prepared from either $\mathrm{Vac}^{+}$or $\mathrm{Vac}^{-}$H. pylori 60190 or with E. coli-conditioned media. The $\mathrm{Vac}^{+}$HPCM substantially decreased BAEC
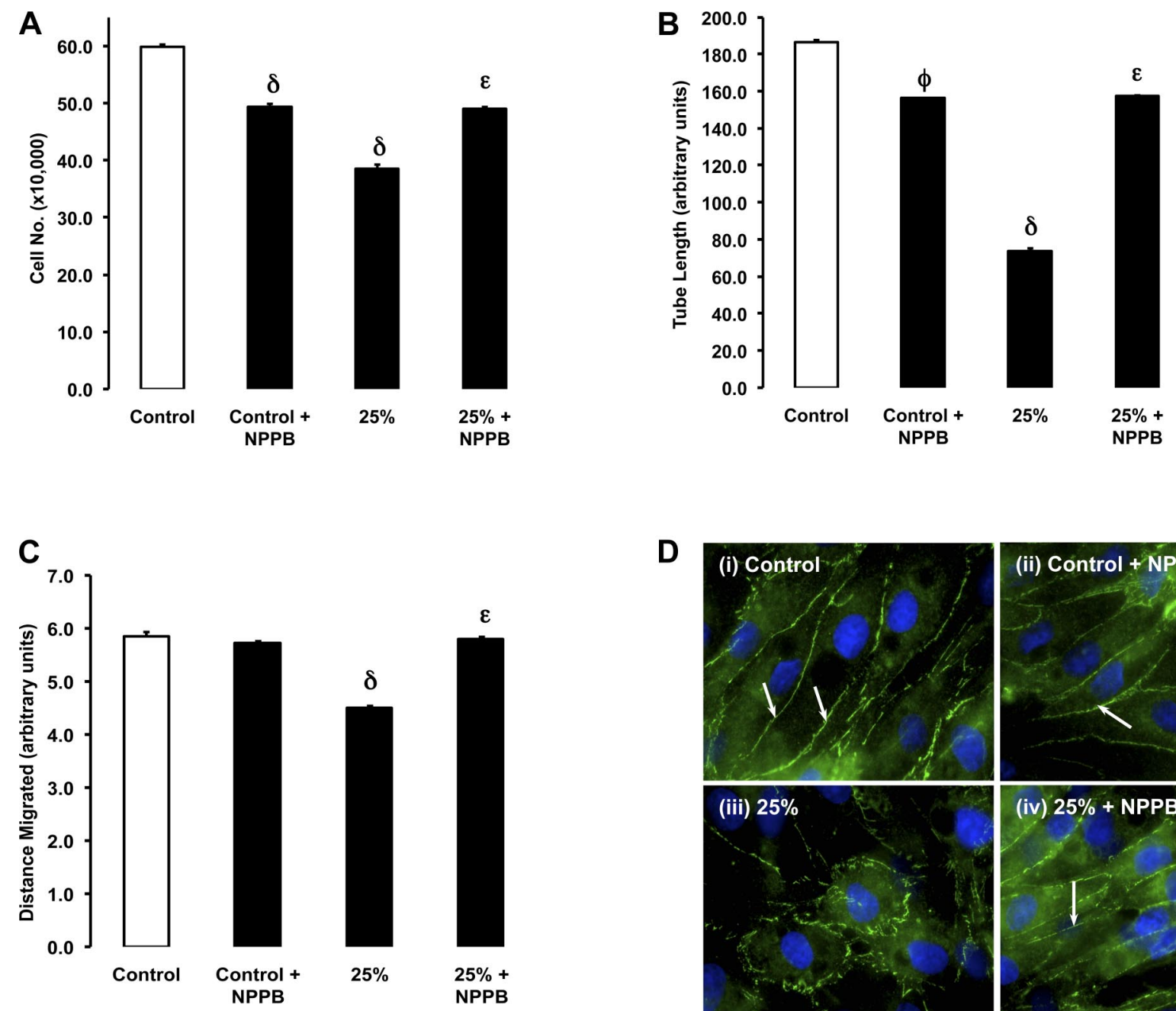
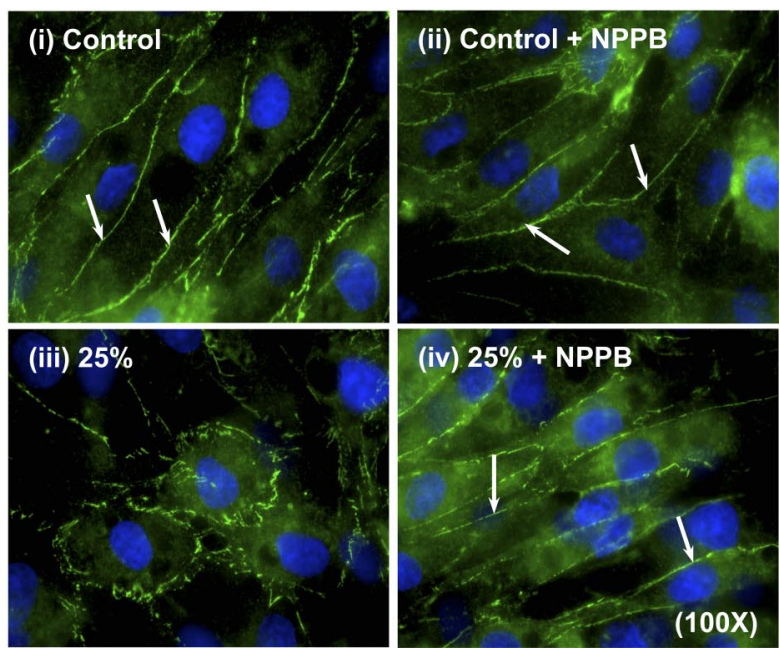

Fig. 2. Effect of 5-nitro-2-(3-phenylpropylamino)benzoic acid (NPPB) on HPCM-induced changes in BAEC functions. BAECs were treated with Vac ${ }^{+} \mathrm{HPCM}$ $(25 \%)$ in the absence and presence of $100 \mu \mathrm{M}$ NPPB and monitored for changes in proliferation (2 days), tube formation (24 h), migration (24 h), and barrier integrity $(24 \mathrm{~h})$. Control is unconditioned RPMI complete media. HPCM treatment times are shown in parentheses. Histograms were averaged from 3 independent experiments \pm SE. $A$ : proliferation. $\delta P \leq 0.0001$ vs. control; $\varepsilon P \leq 0.001$ vs. $25 \%$. $B$ : tube formation. $\phi P \leq 0.001 ; \delta P \leq 0.0001$ vs. control; $\varepsilon P \leq 0.0001$ vs. $25 \%$. C: migration. $\delta P \leq 0.0001$ vs. control; $\varepsilon P \leq 0.0001$ vs. $25 \%$. $D$ : barrier integrity. White arrows indicate cell-cell border localization of zonnula occludens-1 (ZO-1) immunoreactivity. 4,6-Diamidino-2-phenylindole (DAPI)-stained nuclei are clearly visible in blue. Images are representative. 
proliferation, tube formation, and migration relative to untreated controls (Fig. 3, $A-C$ ). Neither $\mathrm{Vac}^{-}$HPCM nor $E$. coli-conditioned media, however, had any significant effects.

The impact of VacA on BAEC barrier properties was also examined using a similar treatment paradigm to above. As seen earlier, ZO-1 immunoreactivity along the cell-cell border became highly discontinuous and jagged in response to $\mathrm{Vac}^{+}$ HPCM, consistent with the disruption of intercellular tight junction integrity. Moreover, $\mathrm{Vac}^{+}$HPCM treatment sharply increased FD40 Dextran transendothelial flux across BAEC monolayers (Fig. 4). Again, neither $\mathrm{Vac}^{-}$HPCM nor E. coliconditioned media had any significant effects.

\section{HPCM Decreases BAEC NO Production in a VacA-Dependent Manner}

The effect of HPCM on BAEC NO levels was examined. Cells were treated with either $\mathrm{Vac}^{+}$or $\mathrm{Vac}^{-} \mathrm{HPCM}(25 \%)$ or with $E$. coli-conditioned media. $\mathrm{Vac}^{+}$HPCM substantially decreased NO production relative to untreated controls
(Fig. 5A). Neither $\mathrm{Vac}^{-}$HPCM nor E. coli-conditioned media had any significant effect on NO levels, however, whereas L-NAME (an eNOS inhibitor) almost completely ablated NO production (Fig. 5A). Furthermore, 25\% HPCM $\left(\mathrm{Vac}^{+}\right.$or $\mathrm{Vac}^{-}$) had no significant effect on eNOS total protein levels following $24 \mathrm{~h}$ treatment (data not shown).

\section{HPCM-Induced Changes in BAEC Function Involve VacA-Dependent NO Reduction}

The putative link between HPCM-induced change in BAEC functions and $\mathrm{NO}$ levels was examined. BAECs were treated with $\mathrm{Vac}^{+} \mathrm{HPCM}(25 \%)$ in the absence and presence of SNAP (an NO donor). In the absence of SNAP, HPCM reduced proliferation, tube formation, and migration, as described in BAEC Proliferation, BAEC Migration, and BAEC Tube Formation. These effects were almost completely recovered by SNAP (Fig. 5, $B-D)$.

BAEC barrier properties were also examined in this context. In the absence of SNAP, $\mathrm{Vac}^{+} \mathrm{HPCM}$ (25\%) increased
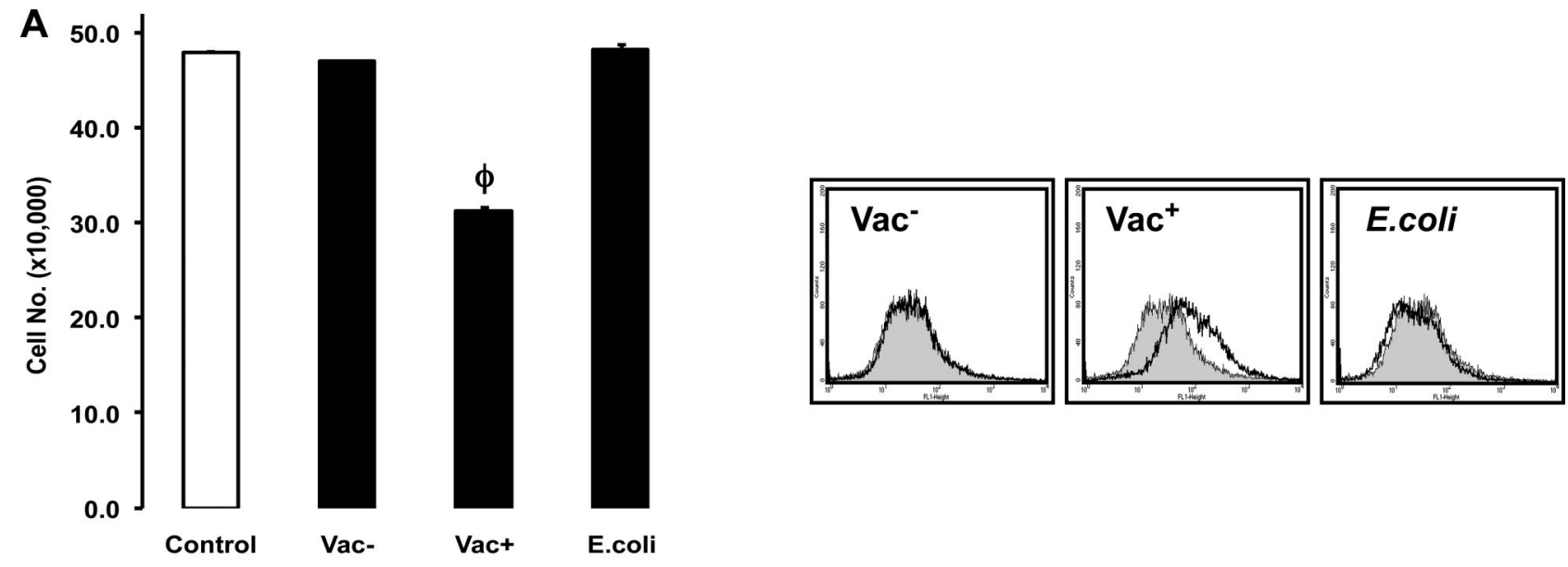

B
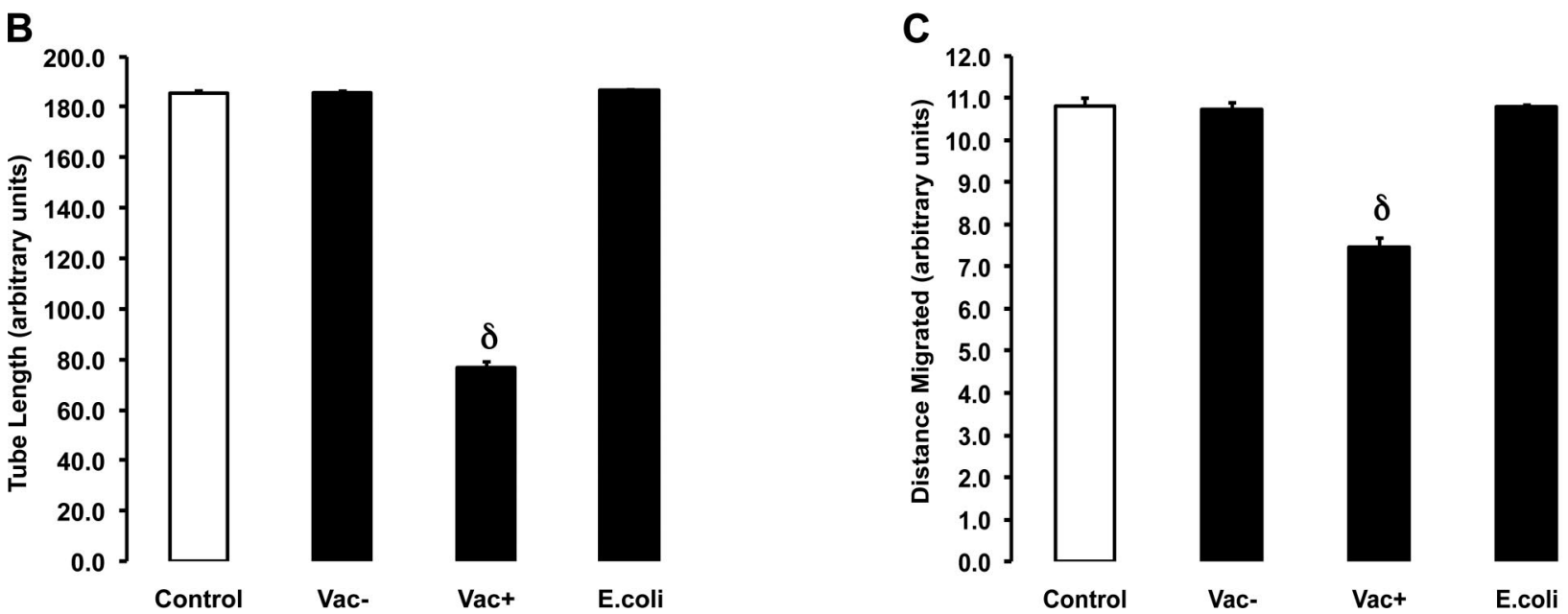

Fig. 3. Effect of VacA on HPCM-induced changes in BAEC functions. BAECs were treated with either Vac ${ }^{+}$or Vac $^{-}$HPCM $(25 \%)$ or Escherichia coli-conditioned media and monitored for changes in proliferation (4 days), tube formation ( $24 \mathrm{~h})$, and migration (24 h). Control is unconditioned RPMI complete media. HPCM treatment times are shown in parentheses. Histograms were averaged from 3 independent experiments \pm SE. $A$ : proliferation. $\phi P \leq 0.001$ vs. control. FACS analysis (right) shows untreated control cells (gray-shaded area) relative to cells treated with conditioned media from either Vac ${ }^{-}$or $\mathrm{Vac}^{+} H$. pylori or wild-type $E$. coli (unshaded areas). $B$ : tube formation. $\delta P \leq 0.0001$ vs. control. $C$ : migration. $\delta P \leq 0.0001$ vs. control. 

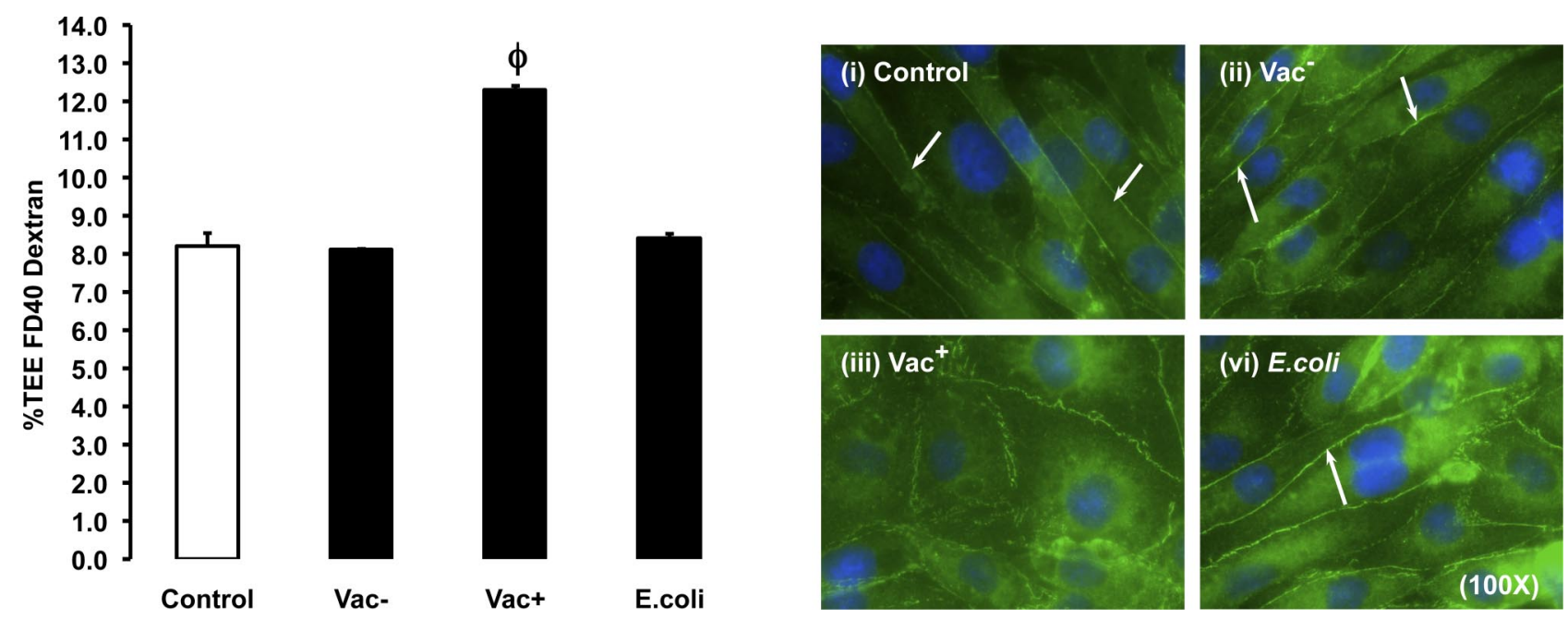

Fig. 4. Effect of VacA on HPCM-induced changes in BAEC barrier properties. BAECs were treated for $24 \mathrm{~h}$ with either $\mathrm{Vac}^{+}$or Vac ${ }^{-} \mathrm{HPCM}(25 \%)$ or $E$. coli-conditioned media, and intact monolayers were monitored for permeability to FD40 Dextran. Control is unconditioned RPMI complete media. Histogram shows percent transendothelial exchange (TEE) of FD40 Dextran as monitored by transwell permeability assay and was averaged from 3 independent experiments \pm SE. $\phi P \leq 0.001$ vs. control. Posttreatment, intact monolayers were also monitored for ZO-1 immunoreactivity (right). White arrows indicate cell-cell border localization of ZO-1. DAPI-stained nuclei are clearly visible in blue. Images are representative.

FD40 Dextran transendothelial flux relative to untreated control (Fig. 6). Moreover, ZO-1 immunoreactivity along the cell-cell border became highly discontinuous and jagged, also consistent with endothelial barrier reduction (Fig. 6). We further observed that either effect could be recovered by SNAP.

\section{HPCM-Induced Changes in BAEC Functions are Absent Under Shear Stress}

The impact of laminar shear stress on the HPCM-induced change in BAEC functions was examined. BAECs were treated with either $\mathrm{Vac}^{+}$or $\mathrm{Vac}^{-} \mathrm{HPCM}(25 \%)$, or with E. coliconditioned media, at a shear rate of 0,1 , or 10 dynes $/ \mathrm{cm}^{2}$. At static and low shear rates, $\mathrm{Vac}^{+} \mathrm{HPCM}$ (but not $\mathrm{Vac}^{-} \mathrm{HPCM}$ or E. coli-conditioned media) substantially decreased NO production (Fig. 7A), proliferation (Fig. 7B), tube formation (Fig. $7 C$ ), and migration (Fig. $7 D$ ) relative to untreated controls. At high shear rate, the inhibitory effects of $\mathrm{Vac}^{+} \mathrm{HPCM}$ on all of the aforementioned BAEC functions were recovered to the high shear baseline levels exhibited by control, $\mathrm{Vac}^{-}$, and $E$. coli treatments (Fig. $7 B-D$ ). Under control conditions, levels of eNOS protein expression were also elevated at high shear (Fig. $7 A$, inset).

\section{DISCUSSION}

This comprehensive study shows, for the first time, a significant proatherogenic effect of $\mathrm{H}$. pylori-secreted factors on a wide range of vascular endothelial dysfunction markers. Our investigations demonstrated that a chronic exposure of BAECs to $25 \%$ HPCM significantly reduced proliferation (while increasing apoptosis and vacuolation at higher concentrations; data not shown). These findings are consistent with earlier studies on $H$. pylori aqueous extracts, which report antiproliferative and proapoptotic effects on human microvascular endothelial cells and umbilical vein endothelial cells $(29,37,52)$. We also observed HPCM-dependent reductions in BAEC tube formation and migration, further evidence that $H$. pylori ex- hibits antiangiogenic properties $(28,29)$. Moreover, the HPCM-induced elevation of BAEC monolayer permeability to FD40 Dextran, in conjunction with sporadic ZO-1 membrane localization, as observed in this study, verifies the barrierlowering properties of $\mathrm{H}$. pylori-secreted factors $(7,8)$, again consistent with earlier reports $(5,15)$.

The cytotoxin-associated gene pathogenicity island and outer membrane proteins are known determinants of $H$. pylori pathogenicity (18). However, these factors require direct bacterium-cell contact, and in the case of the former, a specialized type IV secretion system (23), likely ruling out their contribution to the HPCM effects observed in this study. Other determinants of $H$. pylori pathogenicity include urease and VacA. The former, accounting for almost $10 \%$ of total $\mathrm{H}$. pylori protein, facilitates bacterial colonization in the acidic gastric mucosa (30). The latter functions by forming anion-selective channels in lipid bilayers, thereby modulating membrane depolarization (63). VacA can also enter cells and modulate mitochondrial membrane permeability and cytochrome $\mathrm{C}$ release (59). As both factors are secreted by H. pylori, we hypothesized a role for one or both in the HPCM-mediated effects observed.

When BAECs were treated with unconditioned media in the absence and presence of $10 \mu \mathrm{g} / \mathrm{ml}$ jack bean urease, an enzyme known to display many of the same properties as $H$. pylori urease (48), no significant effects on cell function were observed. The putative role of VacA was next explored. Earlier studies investigating endothelial injury do not clearly identify a role for $\operatorname{VacA}(5,15,28,37,41)$. The barrier-lowering (53), antiproliferative $(50,62)$, and proapoptotic (11) effects of $H$. pylori on other cell types (e.g., gastric epithelial cells, Tlymphocytes), however, have definitively been attributed to this virulence factor. Importantly, a number of these studies confirm the dose-dependent effects of VacA on cell functions and further demonstrate a threshold VacA concentration in the lower $\mathrm{nM}$ range for the induction of these effects. Use of the VacA-selective inhibitor NPPB (63) completely prevented the 

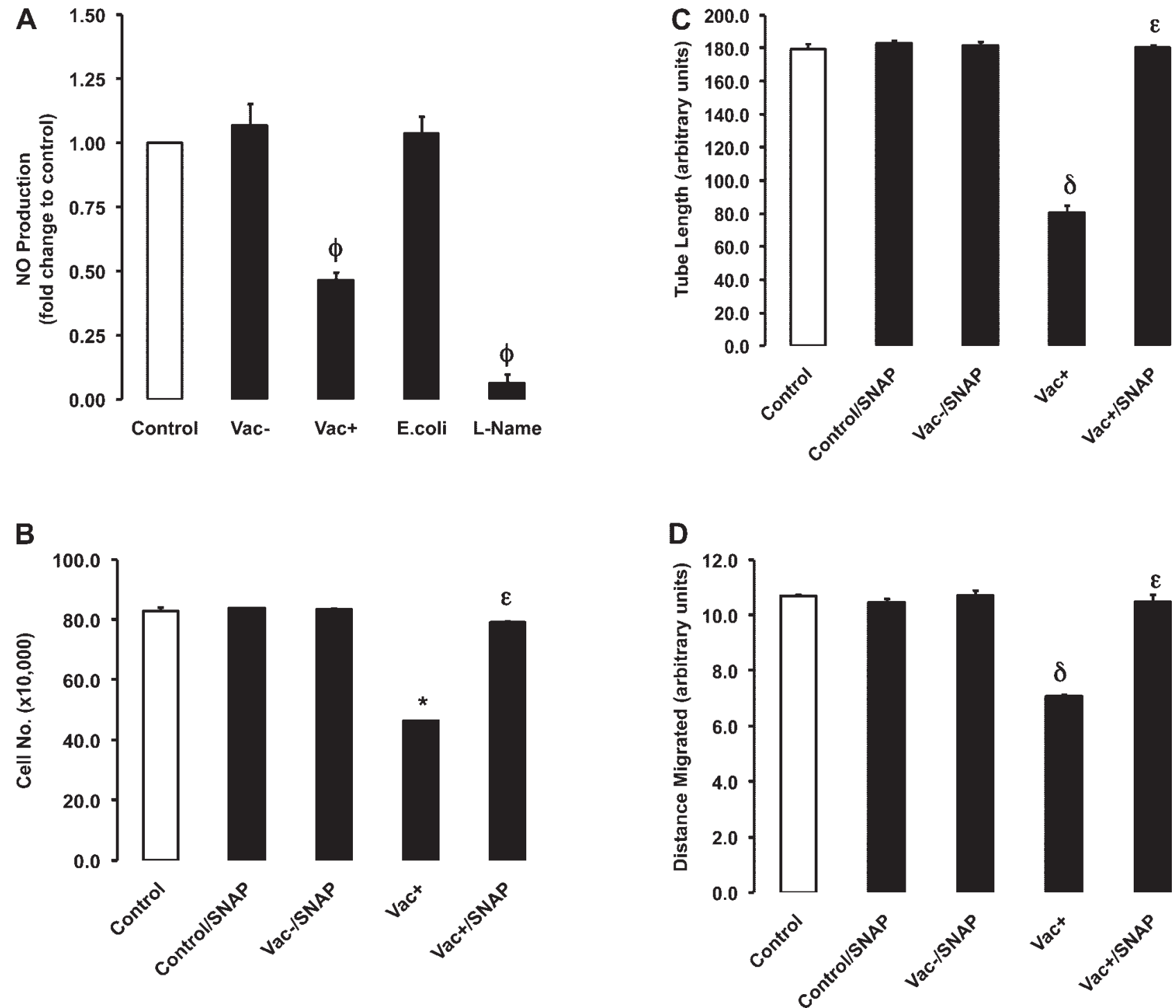

Fig. 5. Effect of nitric oxide (NO) on VacA-dependent changes in BAEC functions. BAECs were treated for $24 \mathrm{~h}$ with either $\mathrm{Vac}^{+}$or Vac ${ }^{-} \mathrm{HPCM}(25 \%), E$. coli-conditioned media, or $N^{\omega}$-nitro-L-arginine methyl ester (L-NAME), and media were subsequently harvested to monitor NO production. Control is unconditioned RPMI complete media. The effects of $S$-nitroso- $N$-acetyl-penicillamine (SNAP) on HPCM-dependent changes in proliferation (4 days), tube formation $(24 \mathrm{~h})$, and migration $(24 \mathrm{~h})$ were also monitored. HPCM treatment times are shown in parentheses. Histograms were averaged from 3 independent experiments \pm SE. $A$ : NO production. $\phi P \leq 0.001$ vs. control. $B$ : proliferation. $* P \leq 0.01 \mathrm{vs.} \mathrm{control;} \varepsilon P \leq 0.0001$ vs. Vac ${ }^{+}$. $C$ : tube formation. $\delta P \leq 0.0001$

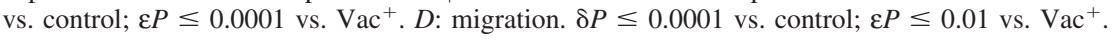

HPCM-dependent effects on all BAEC dysfunction markers examined. This finding clearly points to a highly significant role for VacA in HPCM-induced endothelial injury. The lack of any effects on the aforementioned BAEC functions following treatment with conditioned media from VacA gene-deleted H. pylori $\left(\mathrm{Vac}^{-} \mathrm{HPCM}\right)$ further strengthened this conclusion. Furthermore, the preparation of $\mathrm{Vac}^{-}$and $\mathrm{Vac}^{+}$HPCM from the same strain (60190), in addition to the clear agreement of data from both inhibitor and mutant studies, suggests that the involvement of other bacterium-derived factors is unlikely. Finally, whereas VacA levels were not definitively quantified in our HPCM preparations, the steep concentration dependence at $25 \%$ HPCM, which was particularly notable in our proliferation study (Fig. 1A), possibly reflects a threshold concentration effect as outlined above.
We next considered the cellular mechanism mediating VacA involvement in this model. VacA is a multifunctional toxin that exhibits pleiotropic effects on mammalian cells (10). Its cytotoxic effects are an important feature of cellular injury and pathology. In the human gastric mucosa, for example, VacA causes extensive epithelial vacuolation, proinflammatory cytokine release, and apoptosis, leading to reduced epithelial cell viability and gastric ulceration $(11,50,61,67)$. The importance of VacA cytotoxicity to endothelial dysfunction and atherogenesis in vivo, however, is not understood. It should be noted that the $\mathrm{Vac}^{+}$HPCM range $(0-25 \%)$ chosen for the bulk of these studies did not induce cell vacuolation (phase-contrast microscopy), and it did not reduce cell viability (trypan blue exclusion and propidium iodide incorporation assays; data not shown). This greatly reduces the possibility that the functional 

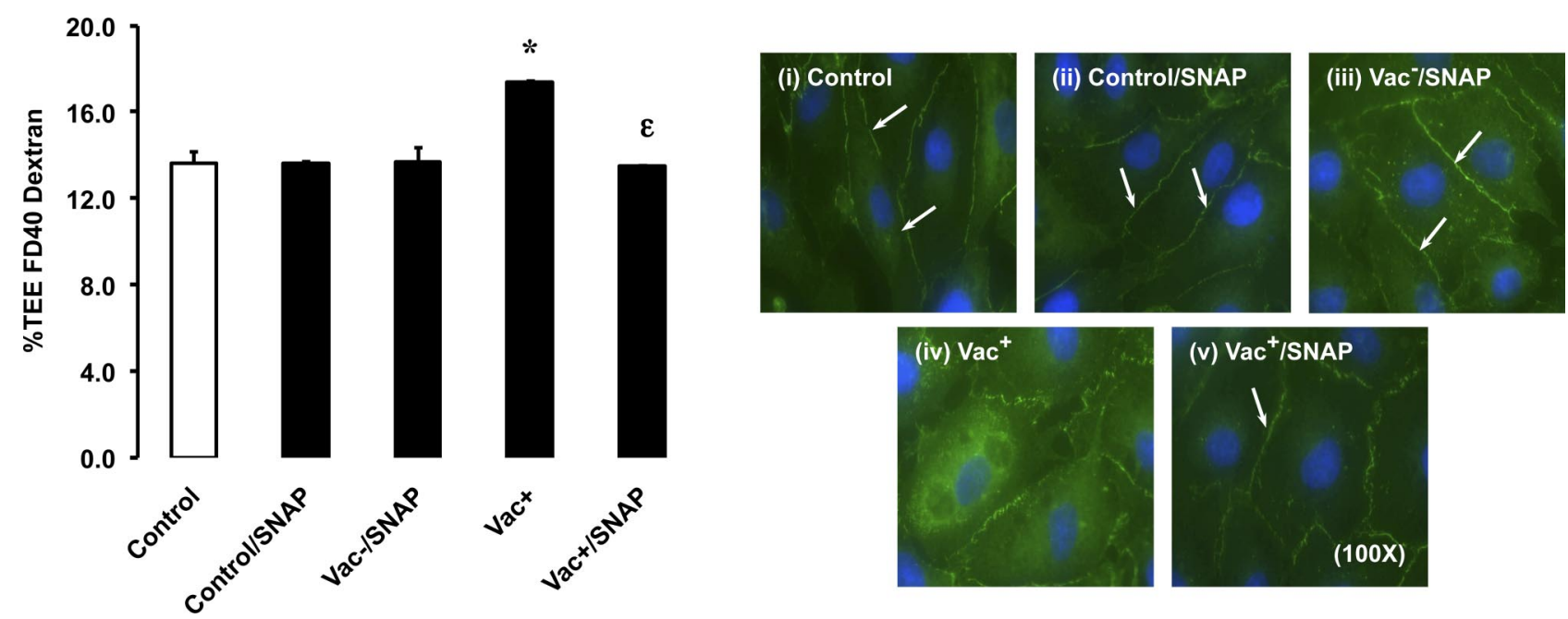

Fig. 6. Effect of NO on VacA-dependent changes in BAEC barrier properties. BAECs were treated for $24 \mathrm{~h}$ with either Vac ${ }^{+}$or Vac ${ }^{-} \mathrm{HPCM}(25 \%)$ in the absence and presence of SNAP, and intact monolayers were monitored for permeability to FD40 Dextran. Control is unconditioned RPMI complete media. Histogram shows percent TEE of FD40 Dextran as monitored by transwell permeability assay and was averaged from 2 independent experiments \pm SE. $* P \leq$ 0.05 vs. control; $\varepsilon P \leq 0.001$ vs. $\mathrm{Vac}^{+}$. Posttreatment, intact monolayers were also monitored for ZO-1 immunoreactivity. White arrows indicate cell-cell border localization of ZO-1. DAPI-stained nuclei are clearly visible in blue. Images are representative.

changes observed are due to cytotoxic actions of VacA and suggests that subtoxic levels of VacA can induce endothelial injury. The well-described ability of VacA to alter cell function independently of its cytotoxic actions $(10,53)$ is therefore relevant to our model and suggests the VacA-dependent modulation of endothelial signaling pathways.

We hypothesized that HPCM-induced endothelial injury could be mediated by VacA-dependent NO reduction. NO plays a key role in vascular homeostatic regulation (59). Endothelial dysfunction and atherogenesis are characterized by reduced NO bioavailability owing to diminished eNOS expression or activation, reactive oxygen species (ROS) overproduction, and inhibition of eNOS activity by either the overproduction/reduced clearance of endogenous ADMA or the induction of an arginase activity. Moreover, previous studies have attributed all of the above mechanisms to $H$. pylori pathogenicity in various gastric and nongastric injury models $(19,41,45,51)$. Correspondingly, treatment of BAECs with $\mathrm{Vac}^{+}$(but not $\mathrm{Vac}^{-}$) HPCM reduced endogenous NO production by over $50 \%$, whereas all of the observed $\mathrm{Vac}^{+}$HPCM-dependent changes in endothelial function could be recovered by an exogenous NO source (SNAP). Importantly, HPCM treatment $\left(\mathrm{Vac}^{+}\right.$or $\left.\mathrm{Vac}^{-}\right)$did not appear to significantly alter total BAEC eNOS protein levels (data not shown), suggesting that the observed HPCM-induced NO reduction is not attributable to eNOS expression changes and that alternate mechanisms (i.e., eNOS activation, ROS production, etc.) are more likely associated with this phenomenon. We further demonstrated that a known stimulus for NO production in vivo, namely laminar shear stress (65), could also recover $\mathrm{Vac}^{+}$HPCMinduced changes in BAEC proliferation, tube formation, and migration. These findings confirm a central role for NO depletion in VacA-induced endothelial injury. Moreover, they further suggest that the atherogenic impact of $H$. pylori in vivo would be most acute at arterial branch points and curvatures, the principal sites of atherosclerotic lesion development, where the atheroprotective influence of laminar shear stress is attenuated (due to turbulence) and NO depletion could be further exacerbated by VacA. A recent study by Liuba et al. (41), in which the authors demonstrate that coinfection of apoE-knockout mice with $C$. pneumoniae and $H$. pylori leads to impaired bioactivity of endothelial NO and increased VCAM-1 expression at arterial branch points, supports this conclusion. Interestingly, shear stress did not appear to prevent the barrierlowering effects of $\mathrm{Vac}^{+}$HPCM. The reasons for this are unknown, although insufficient shear-induced NO production, NO-independent effects of VacA, and/or experimental artifact are possible explanations. A more detailed investigation of the dynamic relationship between shear stress and VacA-induced endothelial injury is therefore warranted.

The precise nature of VacA signaling in vascular endothelial cells is undefined at present, although one can speculate as to the intermediates involved. As a member of the Rho-GTPase family of signaling enzymes, Rac1 integrates multiple signaling events and is known to function upstream of eNOS activation and NO production in vascular endothelial cells in various physiological contexts $(27,34,40)$. Interestingly, the VacA-dependent inhibition of Rac1 has been shown to prevent repair of gastric mucosal injury and ulcer reepithelialization, an NO-dependent process (50). Studies have also recently demonstrated that VacA can induce cellular effects independently of its vacuolating function through the activation of a p38 MAPK stress signaling pathway, which leads to the activation of the transcription factors activating transcription factor-2, cAMP-response element-binding protein, and NF-кB $(24,32)$. Since p38 MAPK activation has also been directly linked to the superoxide-induced reduction of NO bioavailability in different vascular injury models $(56,64)$, this suggests the possible applicability of this signaling pathway to the HPCM-induced NO reduction observed in our BAEC model. Downstream of $\mathrm{NO}$, signaling possibilities are numerous. Of note, $\mathrm{NO}$ is known to inhibit the SNAP receptor-mediated exocytosis of endothelial Weibel-Palade bodies, which mediate vascular inflammation and adaptive remodeling (46). Thus VacA-dependent NO reduction could ultimately lead to the excessive 

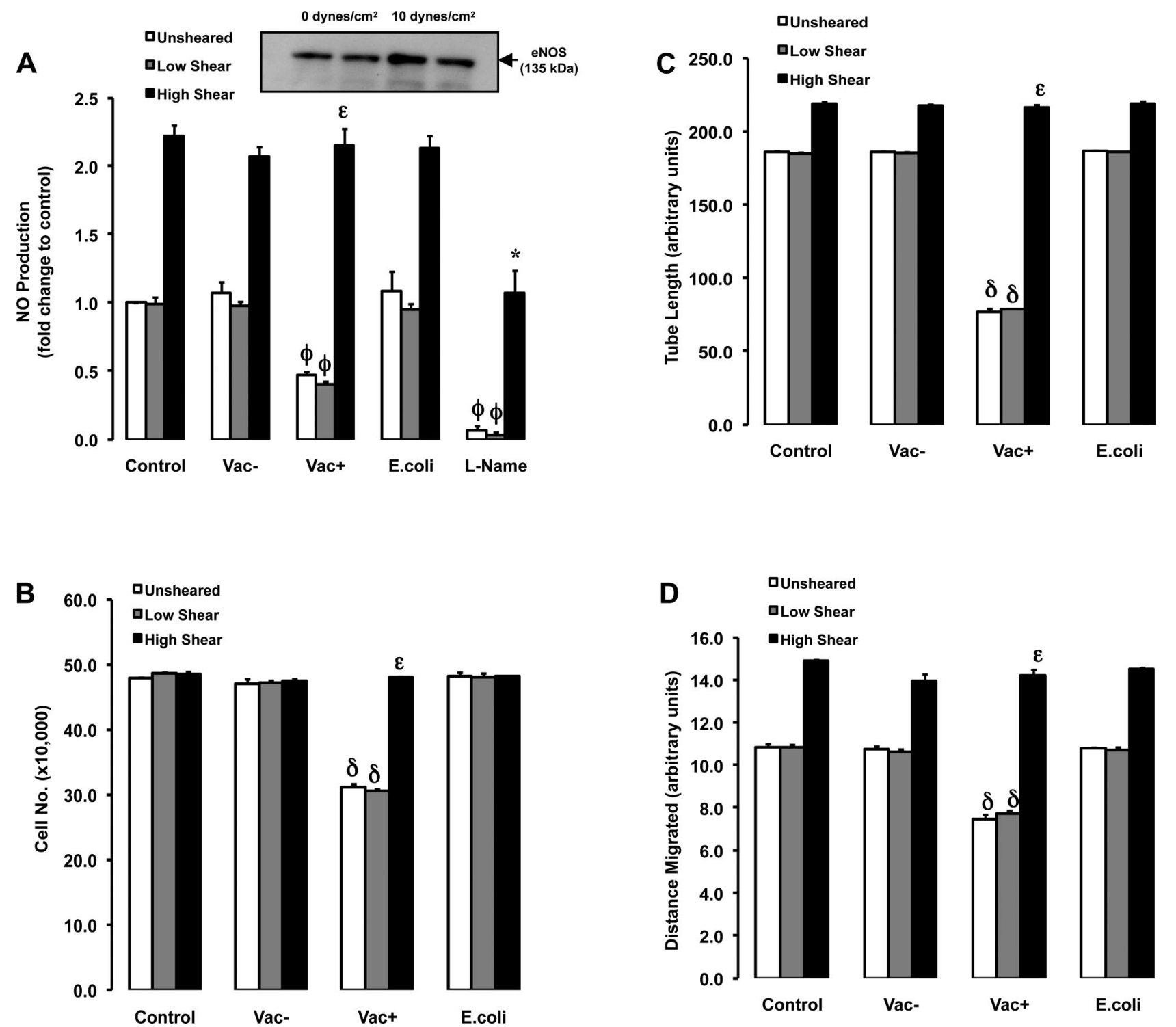

Fig. 7. Effect of laminar shear stress on VacA-dependent changes in BAEC functions. BAECs were treated for $24 \mathrm{~h}$ with either $\mathrm{Vac}^{+}$or Vac ${ }^{-} \mathrm{HPCM}(25 \%)$ or E. coli-conditioned media under static $\left(0\right.$ dynes $/ \mathrm{cm}^{2}$; white), low shear $\left(1 \mathrm{dyne} / \mathrm{cm}^{2}\right.$; gray), and high shear $\left(10 \mathrm{dynes} / \mathrm{cm}^{2}\right.$; black) conditions. Control is unconditioned RPMI complete media. The effects of shear on HPCM-dependent changes in NO production, proliferation, tube formation, and migration were subsequently monitored as previously described. Histograms were averaged from 3 independent experiments \pm SE. $A$ : NO production. $\phi P \leq 0.001$ vs. control; $\varepsilon P \leq 0.0001$ vs. $\mathrm{Vac}^{+}$low shear; $* P \leq 0.01$ vs. control high shear. Inset: representative blot showing effect of shear stress on total endothelial NO synthase

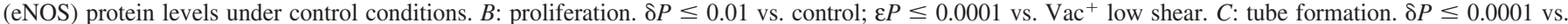
control; $\varepsilon P \leq 0.0001$ vs. Vac ${ }^{+}$low shear. $D$ : migration. $\delta P \leq 0.0001$ vs. control; $\varepsilon P \leq 0.01$ vs. Vac $^{+}$low shear.

release of inflammatory mediators, with predictable consequences for endothelial dysfunction.

To summarize, we have conducted a comprehensive investigation of how $H$. pylori-secreted factors play a role in vascular endothelial injury. With the use of an in vitro aortic endothelial cell model, our findings demonstrate, for the first time, the antiproliferative, antiangiogenic, and barrier-lowering properties of $H$. pylori-secreted VacA, events consistent with endothelial dysfunction. Moreover, the VacA-dependent impairment of endothelial NO bioavailability is strongly indicated in these events, as is an atheroprotective role for laminar shear stress. These findings establish a clearer vascular context in which $H$. pylori infection contributes to endothelial dysfunction and atherogenesis in vivo. Although the precise organiza- tion of the VacA signaling pathway, and indeed its dynamic relationship with shear stress, is beyond the scope of this paper, we have begun to elucidate the cellular intermediates involved and believe the present study provides an excellent foundation for further investigations in this field.

Finally, although the present study adds further weight to a causal relationship between $H$. pylori infection and atherosclerosis, one is mindful of the complex debate surrounding the contribution of the infectious burden to endothelial dysfunction and vascular disease. Indeed, researchers have provided evidence both in support of and against a role for $H$. pylori in this pathophysiological context, findings chronicled primarily through in vivo modeling studies $(41,42)$, epidemiological investigations $(12,20,22,25,49,55)$, and the identification of 
H. pylori DNA in atheromatous vascular tissue $(1,17,36,68)$. We believe that the in vitro plausibility study described in this paper makes an extremely important and timely contribution to this debate and will undoubtedly serve as an important correlate to ongoing clinical/eradication studies directly addressing this issue.

\section{GRANTS}

This research was supported in part through funding from the Health Research Board of Ireland (to G. T. Henehan and P. A. Cahill), Science Foundation Ireland (to P. A. Cahill), and the Higher Education Authority Programme for Research at Third Level Institutes (to P. A. Cahill). Additional financial support was provided through the Science Foundation Ireland, Health Research Board of Ireland, and Enterprise Ireland Basic Research Grant Programmes (to P. M. Cummins and R. P. Murphy) and through Dublin City University (to N. P. Tobin).

\section{REFERENCES}

1. Ameriso SF, Esteban A, Fridman MD, Leiguarda RC, Gustavo E, Sevlever MD. Detection of Helicobacter pylori in human carotid atherosclerotic plaques. Stroke 32: 385-391, 2001.

2. Ameriso SF, Villamil AR, Zedda C, Parodi JC, Garrido S, Sarchi MI, Schultz M, Boczkowski J, Sevlever GE. Heme oxygenase-1 is expressed in carotid atherosclerotic plaques infected with Helicobacter pylori and is more prevalent in asymptomatic subjects. Stroke 36: 1896-1900, 2005.

3. Ando T, Minami M, Ishiguro K, Maeda $\mathbf{O}$, Watanabe $\mathbf{O}$, Mizuno $\mathrm{T}$, Fujita T, Takahashi H, Noshiro M, Goto H. Changes in biochemical parameters related to atherosclerosis after Helicobacter pylori eradication. Aliment Pharmacol Ther 24, Suppl 4: 58-64, 2006.

4. Bradford M. A rapid and sensitive method for the quantitation of microgram quantities of protein utilizing the principle of protein dyebinding. Anal Biochem 72: 248-254, 1976.

5. Brisslert M, Enarsson K, Lundin S, Karlsson A, Kusters JG, Svennerholm AM, Backert S, Quiding-Jarbrink M. Helicobacter pylori induce neutrophil transendothelial migration: role of the bacterial HP-NAP. FEMS Microbiol Lett 249: 95-103, 2005.

6. Coen P, Cummins P, Birney Y, Devery R, Cahill P. Modulation of PGF- $1 \alpha$ and nitric oxide production in bovine aortic endothelial cells by conjugated linoleic acid. Endothelium 11: 211-220, 2004.

7. Colgan OC, Ferguson G, Collins NT, Murphy RP, Meade G, Cahill PA, Cummins PM. Regulation of brain microvascular endothelial tight junction assembly and barrier function by steady and pulsatile shear stress. Am J Physiol Heart Circ Physiol 292: H3190-H3197, 2007.

8. Collins NT, Cummins PM, Colgan OC, Ferguson G, Birney YA, Murphy RP, Meade G, Cahill PA. Cyclic strain-mediated regulation of vascular endothelial occludin and ZO-1: influence on intercellular tight junction assembly and function. Arterioscler Thromb Vasc Biol 26: 6268, 2006.

9. Corrado E, Novo S. Role of inflammation and infection in vascular disease. Acta Chir Belg 105: 567-579, 2005.

10. Cover TL, Blanke SR. Helicobacter pylori VacA, a paradigm for toxin multifunctionality. Nat Rev Microbiol 3: 320-332, 2005.

11. Cover TL, Krishna US, Israel DA, Peek RM Jr. Induction of gastric epithelial cell apoptosis by Helicobacter pylori vacuolating cytotoxin. Cancer Res 63: 951-957, 2003.

12. Davi G, Neri M, Falco A, Festi D, Taraborelli T, Ciabattoni G, Basili S, Cuccurullo F, Patrono C. Helicobacter pylori infection causes persistent platelet activation in vivo through enhanced lipid peroxidation. Arterioscler Thromb Vasc Biol 25: 246-251, 2005.

13. de Jonge HW, Dekkers DH, Tilly BC, Lamers JM. Cyclic stretch and endothelin-1 mediated activation of chloride channels in cultured neonatal rat ventricular myocytes. Clin Sci (Lond) 103, Suppl 48: 148S-151S, 2003.

14. Elkind MS, Cole JW. Do common infections cause stroke? Semin Neurol 26: 88-99, 2006.

15. Enarsson K, Brisslert M, Backert S, Quiding-Jarbrink M. Helicobacter pylori induces transendothelial migration of activated memory $\mathrm{T}$ cells. Infect Immun 73: 761-769, 2005.

16. Espinola-Klein C, Rupprecht HJ, Blankenberg S, Bickel C, Kopp H, Rippin G, Victor A, Hafner G, Schlumberger W, Meyer J. Impact of infectious burden on extent and long term prognosis of atherosclerosis. Circulation 105: 15-21, 2002.
17. Farsak B, Yildirir A, Akyon Y, Pinar A, Oc M, Boke E, Kes S, Tokgozoglu L. Detection of Chlamydia pneumoniae and Helicobacter pylori DNA in human atherosclerotic plaques by PCR. J Clin Microbiol 38: $4408-4411,2000$

18. Figueiredo C, Machado JC, Yamaoka Y. Pathogenesis of Helicobacter pylori infection. Helicobacter 10: 14-20, 2005.

19. Gobert AP, McGee DJ, Akhtar M, Mendz GL, Newton JC, Cheng Y, Mobley HL, Wilson KT. Helicobacter pylori arginase inhibits nitric oxide production by eukaryotic cells: a strategy for bacterial survival. Proc Natl Acad Sci USA 98: 13844-13849, 2001.

20. Grabczewska Z, Nartowicz E, Kubica J, Rosc D. Endothelial function parameters in patients with unstable angina and infection with Helicobacter pylori and Chlamydia pneumoniae. Eur J Intern Med 17: 339-342, 2006.

21. Guo FH, Yan XM, Fan CX, Zhao F, Xiao D, Zeng X, Zhang MJ, He LH, Meng FL, Zhang JZ. Cross-reactivity of anti-H. pylori antibodies with membrane antigens of human erythrocytes. World J Gastroenterol 13: 3742-3746, 2007.

22. Hagiwara N, Toyoda K, Inoue T, Shimada H, Ibayashi S, Iida M, Okada Y. Lack of association between infectious burden and carotid atherosclerosis in Japanese patients. J Stroke Cerebrovasc Dis 16: 145$152,2007$.

23. Handa O, Naito Y, Yoshikawa T. CagA protein of Helicobacter pylori: a hijacker of gastric epithelial cell signaling. Biochem Pharmacol 73: $1687-1702,2007$.

24. Hisatsune J, Nakayama M, Isomoto H, Kurazono H, Mukaida N, Mukhopadhyay AK, Azuma T, Yamaoka Y, Sap J, Yamasaki E, Yahiro K, Moss J, Hirayama T. Molecular characterization of Helicobacter pylori VacA induction of IL-8 in U937 cells reveals a prominent role for p38MAPK in activating transcription factor-2, cAMP response element binding protein, and NF-kappaB activation. J Immunol 180: 5017-5027, 2008.

25. Hoffmeister A, Rothenbacher D, Bode G, Persson K, Marz W, Nauck MA, Brenner H, Hombach V, Koenig W. Current infection with Helicobacter pylori, but not seropositivity to Chlamydia pneumoniae or cytomegalovirus, is associated with an atherogenic, modified lipid profile. Arterioscler Thromb Vasc Biol 21: 427-432, 2001.

26. Innocenti M, Thoreson AC, Ferrero RL, Stromberg E, Bolin I, Eriksson L, Svennerholm AM, Quiding-Jarbrink M. Helicobacter pylori-induced activation of human endothelial cells. Infect Immun 70: 4581-4590, 2002.

27. Jacobson JR, Dudek SM, Singleton PA, Kolosova IA, Verin AD, Garcia JG. Endothelial cell barrier enhancement by ATP is mediated by the small GTPase Rac and cortactin. Am J Physiol Lung Cell Mol Physiol 291: L289-L295, 2006.

28. Jenkinson L, Bardhan KD, Atherton J, Kalia N. Helicobacter pylori prevents proliferative stage of angiogenesis in vitro: role of cytokines. Dig Dis Sci 47: 1857-1862, 2002.

29. Kalia N, Jones C, Bardhan DK, Reed MW, Atherton JC, Brown NJ. Effects of genotypically different strains of Helicobacter pylori on human microvascular endothelial cells in vitro. Dig Dis Sci 46: 54-61, 2001.

30. Kamiya S. Analysis of virulence factors of Helicobacter pylori. Rinsho Byori 49: 116-120, 2001.

31. Kanbay M, Gur G, Yucel M, Yilmaz U, Boyacioglu S. Does eradication of Helicobacter pylori infection help normalize serum lipid and CRP levels? Dig Dis Sci 50: 1228-1231, 2005.

32. Ki MR, Lee HR, Goo MJ, Hong IH, Do SH, Jeong DH, Yang HJ, Yuan DW, Park JK, Jeong KS. Differential regulation of ERK1/2 and p38 MAP kinases in VacA-induced apoptosis of gastric epithelial cells. Am J Physiol Gastrointest Liver Physiol 294: G635-G647, 2008.

33. Konturek PC, Konturek SJ, Pierzchalski P, Bielanski W, Duda A, Marlicz K, Starzynska T, Hahn FG. Cancerogenesis in Helicobacter pylori infected stomach: role of growth factors, apoptosis and cyclooxygenases. Med Sci Monit 7: 1092-1107, 2001.

34. Kou R, Michel T. Epinephrine regulation of the endothelial nitric oxide synthase: roles of Rac1 and beta3-adrenergic receptors in endothelial NO signaling. J Biol Chem 282: 32719-32729, 2007.

35. Kowalski M, Pawlik M, Konturek JW, Konturek SJ. Helicobacter pylori infection in coronary artery disease. J Physiol Pharmacol 57, Suppl 3: 101-111, 2006.

36. Kowalski M, Rees W, Konturek PC, Grove R, Scheffold T, Meixner H, Brunec M, Franz N, Konturek JW, Pieniazek P, Hahn EG, Konturek SJ, Thale J, Warnecke H. Detection of Helicobacter pylori specific DNA in human atheromatous coronary arteries and its association 
to prior myocardial infarction and unstable angina. Dig Liver Dis 34: 398-402, 2002.

37. Kurosawa A, Miwa H, Hirose M, Tsune I, Nagahara A, Sato N. Inhibition of cell proliferation and induction of apoptosis by Helicobacter pylori through increased phosphorylated p53, p21 and Bax expression in endothelial cells. J Med Microbiol 51: 385-391, 2002.

38. Laemmli U. Cleavage of structural proteins during the assembly of the head of bacteriophage T4. Nature 227: 680-685, 1970.

39. Laurila A, Bloigu A, Nayha S, Hassi J, Leinonen M, Saikku P. Association of Helicobacter pylori infection with elevated serum lipids. Atherosclerosis 142: 207-210, 1999.

40. Levine YC, Li GK, Michel T. Agonist-modulated regulation of AMPactivated protein kinase (AMPK) in endothelial cells: evidence for an AMPK-Rac1-Akt-endothelial nitric oxide synthase pathway. J Biol Chem 282: 20351-20364, 2007.

41. Liuba P, Pesonen E, Paakkari I, Batra S, Anderson L, Forslid A, Yla-Herttuala S, Persson K, Wadstrom T, Wang X, Laurini $\mathbf{R}$. Co-infection with Chlamydia pneumoniae and Helicobacter pylori results in vascular endothelial dysfunction and enhanced VCAM-1 expression in apoE-knockout mice. J Vasc Res 40: 115-122, 2003.

42. Mach F, Sukhova GK, Michetti M, Libby P, Michetti P. Influence of Helicobacter pylori infection during atherogenesis in vivo in mice. Circ Res 90: E1-E4, 2002.

43. Manolakis A, Kapsoritakis AN, Potamianos SP. A review of the postulated mechanisms concerning the association of Helicobacter pylori with ischemic heart disease. Helicobacter 12: 287-297, 2007.

44. Manolopoulos VG, Liekens S, Koolwijk P, Voets T, Peters E, Droogmans G, Lelkes P, de Clercq E, Nilius B. Inhibition of angiogenesis by blockers of volume-regulated anion channels. Gen Pharmacol 34: 107$116,2000$.

45. Marra M, Bonfigli AR, Bonazzi P, Galeazzi R, Sirolla C, Testa I, Cenerelli S, Boemi M, Testa R. Asymptomatic Helicobacter pylori infection increases asymmetric dimethylarginine levels in healthy subjects. Helicobacter 10: 609-614, 2005.

46. Matsushita K, Morrell CN, Cambien B, Yang SX, Yamakuchi M, Bao C, Hara MR, Quick RA, Cao RW, O'Rourke B, Lowenstein JM, Pevsner J, Wagner DD, Lowenstein CJ. Nitric oxide regulates exocytosis by $S$-nitrosylation of $N$-ethylmaleimide-sensitive factor. Cell 115: 127-129, 2003.

47. Nabwera HM, Logan RP. Epidemiology of Helicobacter pylori: transmission, translocation and extragastric reservoirs. J Physiol Pharmacol 50: 711-722, 1999.

48. Olivera-Severa D, Wassermann GE, Carlini CR. Ureases display biological effects independent of enzymatic activity: is there a connection to diseases caused by urease-producing bacteria? Braz J Med Biol Res 39: 851-861, 2006.

49. Oshima T, Ozono R, Yano Y, Oishi Y, Teragawa H, Higashi Y, Yoshizumi M, Kambe M. Association of Helicobacter pylori infection with systemic inflammation and endothelial dysfunction in healthy male subjects. J Am Coll Cardiol 45: 1219-1222, 2005.

50. Pai R, Sasaki E, Tarnawski AS. Helicobacter pylori vacuolating cytotoxin (VacA) alters cytoskeleton-associated proteins and interferes with re-epithelialization of wounded gastric epithelial monolayers. Cell Biol Int 24: 291-301, 2000.

51. Panchal PC, Forman JS, Blumberg DR, Wilson KT. Helicobacter pylori infection: pathogenesis. Curr Opin Gastroenterol 19: 4-10, 2003.

52. Pearce HR, Kalia N, Bardhan KD, Atherton JC, Brown NJ. Effects of Helicobacter pylori on endothelial cell proliferation and chemotaxis. Digestion 69: 201-210, 2004.
53. Pelicic V, Reyrat JM, Sartori L, Pagliaccia C, Rappuoli R, Telford JL, Montecucco C, Papini E. Helicobacter pylori VacA cytotoxin associated with the bacteria increases epithelial permeability independently of its vacuolating activity. Microbiology 145: 2043-2050, 1999.

54. Polenghi A, Bossi F, Fischetti F, Durigutto P, Cabrelle A, Tamassia N, Cassatella MA, Montecucco C, Tedesco F, de Bernard M. The neutrophil activating protein of Helicobacter pylori crosses endothelia to promote neutrophil adhesion in vivo. J Immunol 178: 1312-1320, 2007.

55. Prasad A, Zhu J, Halcox JPJ, Waclawiw MA, Epstein SE, Quyyumi AA. Predisposition to atherosclerosis by infections: role of endothelial dysfunction. Circulation 106: 184-190, 2002.

56. Qamirani E, Ren Y, Kuo L, Hein TW. C-reactive protein inhibits endothelium-dependent NO-mediated dilation in coronary arterioles by activating $\mathrm{p} 38$ kinase and $\mathrm{NAD}(\mathrm{P}) \mathrm{H}$ oxidase. Arterioscler Thromb Vasc Biol 25: 995-1001, 2005.

57. Reyrat JM, Pelicic V, Papini E, Montecucco C, Rappuoli R, Telford JL. Towards deciphering the Helicobacter pylori cytotoxin. Mol Microbiol 34: 197-204, 1999.

58. Rouzaire-Dubois B, Dubois JM. $\mathrm{K}^{+}$channel block-induced mammalian neuroblastoma cell swelling: a possible mechanism to influence proliferation. J Physiol 510: 93-102, 1998.

59. Russo G, Leopold JA, Loscalzo J. Vasoactive substances: nitric oxide and endothelial dysfunction in atherosclerosis. Vascul Pharmacol 38: 259-269, 2002.

60. Simionescu M. Implications of early structural-functional changes in the endothelium for vascular disease. Arterioscler Thromb Vasc Biol 27: 266-274, 2007.

61. Sun J, Aoki K, Zheng JX, Su BZ, Ouyang XH, Misumi J. Effect of $\mathrm{NaCl}$ and Helicobacter pylori vacuolating cytotoxin on cytokine expression and viability. World J Gastroenterol 12: 2174-2180, 2006.

62. Sundrud MS, Torres VJ, Unutmaz D, Cover TL. Inhibition of primary human $\mathrm{T}$ cell proliferation by Helicobacter pylori vacuolating toxin (VacA) is independent of VacA effects on IL-2 secretion. Proc Natl Acad Sci USA 101: 7727-7732, 2004.

63. Szabo I, Brutsche S, Tombola F, Moschioni M, Satin B, Telford JL, Rappuoli R, Montecucco C, Papini E, Zoratti M. Formation of anionselective channels in the cell plasma membrane by the toxin VacA of Helicobacter pylori is required for its biological activity. EMBO $J 18$ : 5517-5527, 1999.

64. Tojo A, Onozato ML, Kobayashi N, Goto A, Matsuoka H, Fujita T. Antioxidative effect of $\mathrm{p} 38$ mitogen-activated protein kinase inhibitor in the kidney of hypertensive rat. J Hypertens 23: 165-174, 2005.

65. Traub O, Berk BC. Laminar shear stress: mechanisms by which endothelial cells transduce an atheroprotective force. Arterioscler Thromb Vasc Biol 18: 677-685, 1998.

66. von Offenberg Sweeney N, Cummins PM, Cotter EJ, Fitzpatrick PA, Birney YA, Redmond EM, Cahill PA. Cyclic strain-mediated regulation of vascular endothelial cell migration and tube formation. Biochem Biophys Res Commun 329: 573-582, 2005.

67. Wada A, Yamasaki E, Hirayama T. Helicobacter pylori vacuolating cytotoxin, VacA, is responsible for gastric ulceration. Biochem J 136: 741-746, 2004.

68. Weiss TW, Kvakan H, Kaun C, Prager M, Speidl WS, Zorn G, Pfaffenberger S, Huk I, Maurer G, Huber K, Wojta J. No evidence for a direct role of Helicobacter pylori and Mycoplasma pneumoniae in carotid artery atherosclerosis. J Clin Pathol 59: 1186-1190, 2006.

69. Willhite DC, Cover TL, Blanke SR. Cellular vacuolation and mitochondrial cytochrome $\mathrm{C}$ release are independent outcomes of Helicobacter pylori vacuolating cytotoxin activity that are each dependent on membrane channel formation. J Biol Chem 278: 48204-48209, 2003. 